\title{
El imposible regreso a Itaca
}

\author{
The impossible return to Itaca
}

0 impossivel retorno a Ítaca

María del Carmen Sánchez*

\section{Resumen}

La saga del hombre es un viaje sin regreso, desde su condición nómada hasta los asentamientos urbanos, da pie a valores diferenciados que definen las distintas culturas que se expresan físicamente, a través de las arquitecturas que definen espacios y ciudades. La lectura de la historia humana como memorias acumuladas, tiene múltiples posibilidades de ser revisada en libros o relatos, en imágenes físicas o virtuales que otorgan al lector la oportunidad de reconstruir su propia historia, personal o colectiva, a través de diferentes lecturas interpretativas. Estas realidades construidas, están sometidas a constante evolución a través del tiempo y los avatares sucedidos. Solo su cuidado y mantenimiento garantizan su continuidad a través de la preservación de la memoria y los recuerdos en su lucha contra el olvido.

Palabras clave: Arquitectura. Imagen. Memoria.
El camino...

Cuando emprendas tu viaje hacia Ítaca, debes rogar que el viaje sea largo,

lleno de peripecias, lleno de experiencias... (KAVAFIS, 1999, no paginado). ${ }^{1}$

Arribar, conocer una ciudad, ya sea o no, por primera vez, es una experiencia comparable a visitar una biblioteca: un inmenso mundo de opciones, libros ambicionados, portadas, títulos, imágenes y sugerencias, o recodos, caminos, edificaciones que compiten por atraer nuestra atención, enfocar nuestra mirada, despertar el deseo. Una ciudad se te ofrece, te hace guiños y trata de conquistarte con misterios y paisajes construidos o soñados. Perderse en los recovecos de unas calles desconocidas es como

\footnotetext{
Doctora en Patrimonio Cultural, Universidad Latinoamericana y del Caribe. Especialización en Universidad de Belgrano (Buenos Aires,) Universidad Simón Bolívar y Universidad Central de Venezuela. Profesora titular de Diseño Arquitectónico, Universidad Simón Bolívar, Caracas. E-mail: sanchezmc2010@gmail.com
}

Recebido em 10.08.2018 - Aprovado em 22.09.2018 http://dx.doi.org/10.5335/hdtv.19n.1.8929 
deslizarse hipnotizado entre estantes repletos de libros

Con estas circunstancias de partida, se convierte este recorrido en un ejercicio de crítica constante, es decir, de selección permanente entre todas las opciones disponibles. Un proceso que se realiza de forma consciente o no, bajo la sugestión de aquello que nos impacta más, la imagen que nos detiene o en lo que reparamos con mayor intensidad. Esa imagen que se queda en el recuerdo o se vuelve recurrente, se deriva de las ideas y conceptos de la arquitectura que conforman la línea de pensamiento del observador, internalizados a lo largo de la experiencia del oficio y de la reflexión disciplinar.

Esto hace que la misma ciudad sea diferente para cada visitante, una experiencia sensible, personal y única, que conectada con nuestra interioridad, es visualizada de tantas maneras como formas de pensamiento, y en ello radica su magia, se revela, se desprende de sus velos, y se muestra según quien y en que momento la observe. Permite múltiples lecturas, múltiples visitas y cambia su rostro de acuerdo al momento existencial del observador.

$\mathrm{Al}$ revisar las fotografías tomadas desde en el intento de fijar el recuerdo y guiadas por el sentimiento que toma el mando sobre la razón, se comprueba, que la mayoría de las imágenes, corresponden a suelos, aceras y calles. La urbanidad, lo público, la voluntad de hacer, cuidar y querer la ciudad. Nuestras carencias.

Las ciudades son la "foto de familia", donde todos los personajes conviven y comparten, abuelos, hijos y nietos, generaciones diferentes en sus ropajes y acentos pero con un innegable aire familiar que las unifica y las singulariza. Son cúmulos de experiencias, aciertos y desaciertos, como algún invitado no deseado que se entromete en su imagen pero que por contraste, puede enriquecer el conjunto. Experiencia única, personal e íntima que no se puede repetir, una lectura que no depende del texto sino del lector. Nunca se regresa a la misma ciudad, nunca se regresa a Ítaca...

\section{El olvido y el recuerdo}

La memoria da cuerpo a los recuerdos y lugar a la Historia, revisada como la recolección de recuerdos conservados a través de diferentes imágenes que pueden ser leídas, contadas, soñadas o construidas en piedra. Estas, las mas duraderas dan lugar a la arquitectura que genera los espacios, las edificaciones o monumentos y los recorridos que definen las ciudades.

En sus últimas obras el filósofo Paul Ricoeur (2002) ha planteado teorías sobre la ciudad como memoria y la arquitectura como relato, entendido como tiempo relatado y tiempo construido. Ideas aplicadas al espacio arquitectónico como realidad material inteligible. Las reflexiones a propósito de la memoria necesaria, con inmensas distancias temporales (RICOEUR, 2002), son expuestas por Agustín de Hipona en Las Confesiones (siglo IV), donde propone el recuerdo como "el presente del pasado", la espera como "el presente del futuro" y la atención como "el presente del presente". La historia como memorias acumuladas, es el recuento del recorrido humano basado en 
recuerdos, secuencia de narraciones transportadas, de boca a boca, o a través de diferentes vías.

La memoria construida físicamente está expuesta al deterioro, la transformación o la desaparición, pero puede ser mantenida o recuperada a través de múltiples fuentes, imágenes arquitectónicas de la propia documentación de la obra, planos, estudios o investigaciones previas, así como fotografías, grabados o textos revisados con una visión hermenéutica que permitan reconstruir los recuerdos que pertenecen al patrimonio cultural de la humanidad.

Proteger estas arquitecturas no consiste en momificarlas, es permitir su evolución con el fin de adaptarse al violento ritmo de los tiempos comprimidos y lapsos minimizados, que se acortan permanentemente al paso de la tecnología y los cambios sociales, en evolución constante y vertiginosa. Se trata de reconstruir, Pérez Oramas (1997) de erigir una estructura de palabras, de ideas o de muros, que permita el acontecimiento de una experiencia, un acto nuevo en el presente.

La actuación sobre estos objetos arquitectónicos conducen a una arquitectura recobrada del olvido, rescatada de su construcción interrumpida, que abandona el edificio en las manos del tiempo. Su ruina es lo que queda, la imagen del silencio... Es el libro de piedra que se lee de cerca o de lejos, son las imágenes que recogen la historia y conforman el Patrimonio de la cultura, la herencia social que aporta y refuerza el conocimiento de la propia identidad. La recuperación de las arquitecturas olvidadas, lleva a Paul Ricoeur (2002) a establecer un paralelismo muy completo entre las categorías básicas para poner en práctica el proceso. Plantea cómo el "diálogo" entre lo nuevo y lo viejo se establece sin concesiones a la copia, con sumo respeto a lo existente que se mantiene intacto. El respeto no implica sumisión y copia, sino lo contrario: invención e interpretación.

En 1988 la ciudad de Lisboa sufre un incendio devastador, que acaba con barrios y edificaciones de alto valor para la ciudadanía. Se propone al arquitecto Álvaro Siza Vieira la restauración de los daños. Su proyecto causa fuertes discusiones sobre los criterios utilizados y surgen propuestas de modernización de la zona, con la destrucción total de lo existente. Como respuesta, al comienzo de sus obras ya aprobadas, el arquitecto Siza, citado por Pérez Oramas (1997), expresa... esos monumentos o esas casas que tienen la fuerza de los siglos, ¿Cómo puedes demolerlos incluso para reemplazarlos por algo mas hermoso?... han sufrido modificaciones, ha transcurrido la historia y han cambiado progresivamente... acompañando los cambios de programa y de época... evolución discreta y real en relación con los cambios de vida...

A propósito de las posiciones enfrentadas Muntañola (2002) expone que tanto los defensores de la momificación de las ciudades y su memoria por una parte, y los defensores de que destruir es ya innovar por la otra, ambos devienen en destructores por igual de la memoria. La arquitectura necesaria es la que consigue el equilibrio vital entre el olvido y el recuerdo. Es la que soluciona simultáneamente el objeto en sí y su relación con el contexto, de tal manera, que 
el contexto antes y después de la construcción continúe permaneciendo en la memoria. Su pérdida daría pie al cumplimiento de las amenazantes palabras que el escritor George Orwell en 1949, pone en boca del protagonista de su novela 1984: "era imposible aprender historia a través de los monumentos y de la arquitectura. Las estatuas, inscripciones, lápidas, los nombres de las calles, todo lo que pudiera arrojar luz sobre el pasado, había sido alterado sistemáticamente..." (1949, p. 103).

\section{La memoria, el tiempo y la materia}

La voluntad de inmortalidad es inherente a la condición humana, la inquietud ante la muerte se refleja en la necesidad de trascendencia, es decir, perdurar más allá de esta etapa. Proteger su patrimonio primigenio se podría considerar el primer acto de resguardo patrimonial de la saga humana, a partir del momento en que se guardan o entierran los restos humanos con intencionalidad de preservación a través de ritos fúnebres. El objetivo de todos los procesos de conservación es defender o recobrar la significación y el valor cultural de los elementos que están en riesgo para el individuo o el grupo social. En la preservación de la cultura es donde se encuentra el mejor aliado contra el olvido.

Una sociedad determina su identidad cultural como resultado de la suma de conocimientos, creencias y valores compartidos. Se impone normas y costumbres desde distintos puntos de vista, religiosos, históricos o simbólicos, que generan múltiples variantes culturales, como consecuencia del intercambio de conocimientos que produce la cuantiosa diversidad cultural. La cultura adquiere formas diversas a través del tiempo y del espacio. Constituye el patrimonio común de la humanidad y debe ser reconocida y consolidada en beneficio de las generaciones presentes y futuras. Se trasmite en múltiples formas como patrimonio, entre otras, manifestaciones culturales, creaciones artísticas y formas de habitar.

El paisaje cultural, es producido por la acción conjunta del hombre y la naturaleza, y constituido por la morfología del territorio y el accionar humano, es decir, el hombre como productor de cultura. Históricamente ha desarrollado su acción sobre dicho paisaje modelándolo, desde sus orígenes hasta la actualidad. La estructura urbana, como el resultado de los largos procesos históricos, queda registrada en el sentimiento social y materialmente, en el urbanismo y la arquitectura. Las ciudades son procesos temporales de construcción permanente donde el pasado se proyecta en el presente. Conjunto de bienes edificados en los que cada sociedad reconoce un valor cultural. Se cambian los conceptos abarcando un número cada vez mayor de arquitecturas, en este proceso se pasa de la arquitectura representada por los monumentos, a los conjuntos, al centro histórico, al sitio histórico, al paisaje cultural y otras. Este paisaje histórico urbano surge de la percepción visual y del contexto físico en que se genera. Solo el tiempo es capaz de consolidar los bienes patrimoniales, herencia sostenida desde la contemporaneidad consciente para las futuras generaciones. 


\section{Recuperar la ausencia}

Planteando el olvido como la ausencia de recuerdos y la pérdida de la huella de lo vivido, de las personas, las vivencias y las experiencias, los recuerdos son las imágenes mentales que activan la memoria y se ofrecen en forma visual para recuperar estas ausencias. Con su recuperación se garantiza el patrimonio público o privado, y la continuidad de la historia individual o colectiva a través de los paisajes urbanos donde se desarrolla.

Es indispensable revisar la evolución y desarrollo de las ciudades a través de los documentos que registran sus cambios, mapas y planos, imágenes fotográficas o dibujos, grafismos sobre muros, placas de calles o cualquier otras huellas existentes desde su orígenes hasta el presente. Estos documentos conforman textos que relatan, no solo su crecimiento físico condicionado tanto por su estructura geográfica, como también por las decisiones políticas y económicas que tuvieron lugar en los diferentes momentos del desarrollo. La estructura del lugar planteada en sus planos, es donde las relaciones entre sus espacios constitutivos establecen usos, recorridos y formas de habitar. De la lectura interpretativa de estos mapas y planos se puede inferir, cómo evolucionó la sociedad que habitaba la ciudad representada. Los ciudadanos y la ciudad establecen la sinergia que modifica costumbres, usos o tradiciones, son actores inseparables a la vez que observadores de la escena ciudadana. Esta relación entre la ciudad y su ciudadanía se produce en los espacios públicos, centros de intercambio y de encuentro.
El visitante se apropia del espacio vacío y lo llena con actos de conducta social, estableciéndose una conexión entre el espacio y las experiencias de vida de las personas. Se pueden deducir conductas ciudadanas a través de la revisión de los planos leídos como textos escritos en lenguaje gráfico, por las manos del ciudadano preparado para ello en el momento de su realización, sin embargo, para acercarse mejor a esta comprensión es necesario, leer otros "textos" documentales, como son los registros fotográficos.

Estas imágenes efectuadas en diferentes momentos históricos, pueden estar producidas tanto por un aficionado inexperto, tomadas al paso como recuerdos con la intención de retener en el tiempo un instante importante de su historia privada, o registrar un hecho novedoso en la ciudad que involucra la historia colectiva, una inauguración edilicia, un incidente o la creación de nuevos espacios importantes que representen el progreso del momento. La lectura interpretativa de estas imágenes documentales, planos o fotografías, se complementan entre si para comprender mejor las respuestas y reacciones de los actores que forman la ciudadanía.

\section{La imagen revelada}

Desde sus inicios la fotografía, como un símbolo de la modernidad y un modo de representación propio de la época industrial, se integra rápidamente en ámbitos sociales diversos y comienza a utilizarse ampliamente para distintos fines, como la producción, organización y explotación de conocimientos, en el ámbito científico y asi- 
mismo en el ámbito disciplinario, político y propagandístico.

Cumple un papel muy importante en la cultura que se genera actualmente y para la imagen fotográfica (VILCHES, 1984), entre otros documentos visuales, es un instrumento de extracción de información, el registro de un instante en que se congela un momento que ayuda a recuperar la memoria. Las imágenes en la comunicación de masas se transmiten en forma de textos culturales que contienen un mundo real o posible, incluyendo la propia imagen del espectador.

La fotografía se convierte en una fuente visual y herramienta fundamental para distintas disciplinas de las ciencias sociales. Inicialmente asociada con la veracidad, objetividad y valor documental, las imágenes fotográficas tienen que ser sometidas a un proceso de contextualización e interpretación específicas como fuentes de información al igual que los documentos textuales. Se plantea (BARTHES, 1990) como toda fotografía es un sistema de representación connatural con su referente, no es la cosa real a la que remite una imagen o un signo, sino "la cosa necesariamente real" que ha sido colocada ante el objetivo y sin la que no habría fotografía, dice entonces, que la cosa ha estado allí, lo que decide llamar "esto ha sido" y considerada como texto, debe asociarse a su propio contexto de producción.

Cada imagen que aparece en una foto es entendida de forma distinta por los diversos lectores, cada quien tiene un punto de vista diferente al de los demás, lo que produce una interpretación variable basada en los referentes propios que definen la manera en la que se ve el mundo. Una foto al ser una pieza gráfica que solo transmite cierta información deja a la imaginación el resto, permitiendo que cada quien arme una historia diferente a partir de una misma imagen. Como acto hermenéutico que es, hay un texto, un autor y un intérprete, la sutileza interpretativa consiste en captar la intencionalidad significativa del autor, a pesar de la intencionalidad del intérprete. Esto para Lizarazo (2004) determina una cualidad mágica que tiene la fotografía, no solo muestra lo que alguien decidió retratar por su motivo particular, sino que además evoca sensaciones, emociones o recuerdos en quienes la observan. La imagen no es un hecho aparte de la mirada "las miradas contribuyen a construir las imágenes y las imágenes erigen sus miradas [...] no hay práctica interpretativa icónica que no sea, de alguna forma, una manera de coproducir su significación y su sentido" (2004, p. 15-16).

La revisión documental de imágenes visuales no puede dejar de incluir las de publicidad y propaganda, que actúan directamente sobre los esquemas de valores sociales trasmitidos en el momento de su difusión. Se puede considerar que como modelos de propaganda, promueven una forma de vida y reflejan las aspiraciones de la población en un determinado momento social así como de la situación política y económica en que se desenvuelven. Buscar claves de la ciudad o la sociedad que fue desde el presente, se logra entendiendo que el tiempo queda plasmado en el mundo físico dejando huellas en la trama urbana, y siguiendo su rastro a través de ła revisión de 
los documentos visuales preservados que reflejan la condición previa.

De acuerdo con el pensamiento del arquitecto Mies van der Rohe $^{2}$ reflejado en una de sus más difundidas frases, cuando expresa que la arquitectura es la voluntad de una época traducida a espacio. La mayor dificultad de la fotografía de arquitectura radica, no en plasmar la imagen del edificio construido, la materia obra del hombre, sino el vacío que lo envuelve y determina su contexto, en su relación con las demás piezas que componen la trama urbana. Para poder comprender la escala del espacio, observado desde la perspectiva peatonal, es necesario tener en la imagen referentes comparativos, como la presencia de personas o artefactos de dimensiones reconocibles, y elementos físicos o no que definen su borde.

Entre los documentos visuales se pueden encontrar fotografías de diferente factura, como las fotos familiares tomadas al paso y las profesionales destinadas a la difusión, además de los esquemas o gráficos publicados en libros o en revistas nacionales e internacionales. Utilizadas como un texto visual, las imágenes son un discurso argumentativo que se transforma en un valor desde el aspecto patrimonial donde el detalle de la evidencia visual puede preservar un contexto constante en el presente. Depende de las características propias de las imágenes y de la información que se pretenda trasmitir, decidiendo la organización espacio-temporal que mejor cumpla estos objetivos de manera similar que en un texto escrito.-

La documentación fotográfica de imágenes de arquitectura, está dispuesta en relación con los distintos puntos de vista del observador, incluyéndose los tiempos diversos de su creación. La mirada anónima puede captar la imagen total, el paisaje que se produce entre los elementos constitutivos. No se retrata a una persona sino a la ciudad como síntesis. La mirada del observador se puede alejar para contemplar y comprender mejor la circunstancia, la dimensión y el uso posible de este espacio. Es a través de estas miradas plasmadas en imágenes, que se puede leer las evoluciónes urbanas y sociales.

\section{Entre tumbas, templos y palacios}

A través del patrimonio construido como herencia colectiva de la especie humana, podemos "leer" como en un enorme libro, la historia de la humanidad a lo largo de los tiempos y las geografías planetarias. A través de la arquitectura como obra humana se puede comprender los valores y las motivaciones que definieron las diferentes culturas a lo largo de la historia. Dentro de la inmensa variedad de edificaciones construidas, se pueden destacar tres tipologías edificatorias que han sobrevivido el paso secular y se encuentran en todas las culturas, como son las tumbas, los templos y los palacios. Son obras trascendentes en el tiempo y la geografía humana, surgen como respuestas a preguntas, dudas o misterios comunes a la especie: la muerte, lo desconocido y el poder.

La inquietud ante la muerte se refleja en la necesidad de trascendencia, perdurar mas allá de esta etapa. La "humanización" de la especie se puede considerar a partir del momento en que guardan o entierran los 
restos humanos con respeto e intencionalidad a través de ritos fúnebres. Proteger su patrimonio primigenio, se podría considerar el primer acto de resguardo patrimonial de la saga humana. La muerte genera los grandes monumentos Funerarios que llegan hasta nuestros días. La búsqueda de respuestas a lo desconocido, a los fenómenos naturales, al "más allá", a todos los miedos e incertidumbres, se expresan en rituales religiosos que se cobijan en espacios de culto y surgen los Templos, custodios del poder divino. Los Palacios donde reside el poder humano, pueblan la tierra y asumen diferentes estructuras espaciales a lo largo del tiempo y las evoluciones culturales y sociales. Estas tres tipologías comparten desde sus diferentes conceptos, un requisito que les es común, y que asimismo responde a una necesidad humana tan importante como el cobijo, la alimentación y la supervivencia, que es la Belleza.

\section{Memorias acumuladas}

La cueva representa las entrañas de la tierra, el refugio materno, la protección primigenia y el último elemento que acoge y con el que se funde el cuerpo. Se sale de la tierra y se regresa a ella, nunca se abandona por completo. Las cuevas dan el cobijo a los primeros humanos, el homo habilis capaz de crear instrumentos y modificar su mundo, intervenidas por el hombre se cubren de grabados y pinturas que dejan la huella de los que se fueron con significados religiosos o cotidianos, y como en el caso de la Cueva de Altamira, son máxima representación del espíritu creador del hombre, espacios consi- derados la Capilla Sixtina del Arte Rupestre del Paleolítico.

Las técnicas artísticas, el tratamiento de la forma y el aprovechamiento del soporte, los grandes formatos y la tridimensionalidad, el naturalismo y la abstracción, el simbolismo, todos estos conceptos están presentes en Altamira. Su ocupación por el hombre data de 18.000 años atrás y se ubica en la costa cántabra del norte de España.

Figura 1 - Cuevas de Altamira, Periodo Paleolítico, Salón de los Búfalos, Cantabria, España

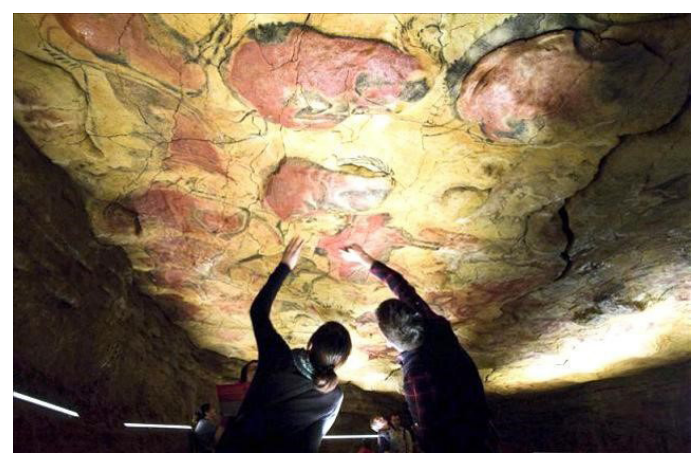

Fuente: <https//lawebdelacultura.com/arquitectura/cuevas-de-altamira>. Acceso en: 12 abr. 2018.

Este arte rupestre, de extrema fragilidad se ha conservado durante milenios gracias a la estabilidad y el aislamiento de la cueva. No puede ser restaurado ni es posible crearle un clima artificial, las experiencias previas han fracasado y sus visitas son muy limitadas. Como respuesta a esto, Altamira he creado una "Neocueva" réplica exacta de la original con lo que se permite acercarse a esta "realidad" sin interferir en los estudios y reinterpretaciones que continúan llevándose a cabo en su interior los investigadores. Su respeto a la obra y la responsabilidad ante el futuro compromete a toda la comunidad humana. 
Búsquedas similares se pueden observar en estructuras ceremoniales como Stonehenge, conjunto megalítico ubicado en el Reino Unido, prueba del genio creativo de los seres humanos del Neolítico. Formado por círculos de menhires de gran tamaño sobre los que se apoyan horizontalmente dinteles de piedra, cuyo significado astronómico no ha sido dilucidado y se debate entre templo para la adoración del sol, centro de sanación, lugar de enterramiento o tal vez un gigantesco calendario.

En los primeros imperios que marcan el proceso civilizatorio, Egipto reúne en sus templos-palacios, Luxor, Karnac, o Abu Simbel, el poder de los dioses y el poder de los hombres, que aunados a los grandes monumentos funerarios, las Pirámides de Giza, siembran toda su geografía de estos símbolos del poder, que se cubren con las mejores obra de artistas, escultores y constructores.

Figura 2 - Templo de Abu Simbel, Asuán, Egipto, 2.500 a. C.

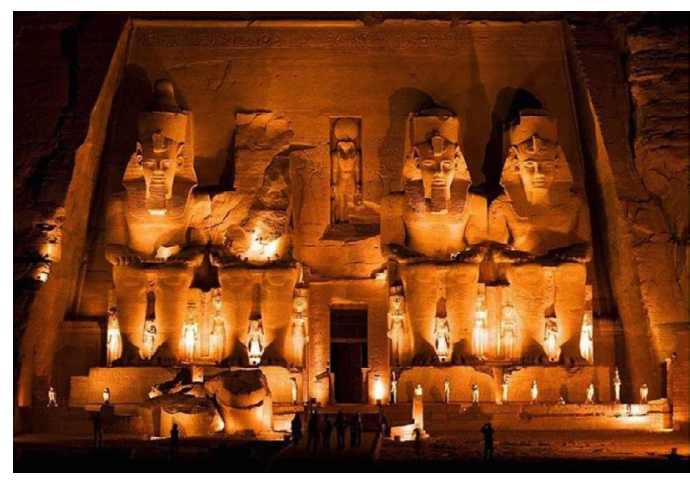

Fuente: <https://gestion.pe/tendencias/templos-increibles-mundo-construidos-rocas-130305>. Acceso en: 20 mar. 2018.

En la zona de Nubia el faraón Ramses II construye el templo de Asuan, con cuatro estatuas colosales talladas en la roca de la pared del acantilado y rodeado de otros importantes monumentos. En 1960 este conjunto corre el peligro de ser inundado por el rio Nilo debido a la construcción de la represa de Asuan. Ante la posibilidad de la pérdida de estos templos faraónicos la UNESCO promueve una campaña internacional para su rescate. Se desmontan los monumentos y se trasladan pieza por pieza a territorios mas elevados donde se reconstruyen con absoluta semejanza a la imagen de su posición anterior.

Figura 3 - Rescate del Templo, Desmontaje de las Piezas, Corte donde se aprecia el escavamiento en la roca

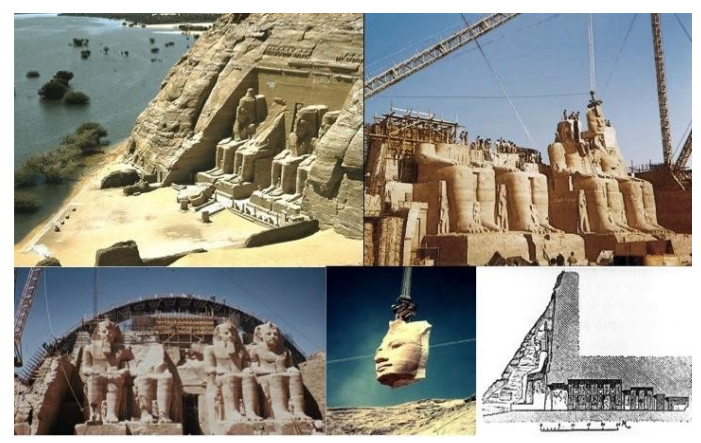

Fuente: montaje de la autora.

Esta es una de las obras de rescate más importantes y riesgosas de las ejecutadas hasta ahora, ante el riesgo de perder varios milenios de memoria se enfrentaron las dificultades de esta batalla contra el tiempo para beneficio de la humanidad. A finales del siglo XVIII, un destacamento militar francés, descubre el más importante texto en piedra conocido hasta la fecha, en suelo egipcio. Este texto es conocido como Piedra Rosetta, enorme pieza de 76 toneladas con superficie pulida que formaba parte de una antigua estela. Textos grabados en 
tres idiomas, jeroglífico egipcio, demótico y griego antiguo. Su significado lo descifra J. F. Champollion 1822 y en la actualidad se encuentra en el Museo Británico de Londres. La humanidad no puede abandonar la lectura de las piedras.

Figura 4 - Piramides de Giza, Conjunto funerario, Menfis, Egipto, 3000 a. C.

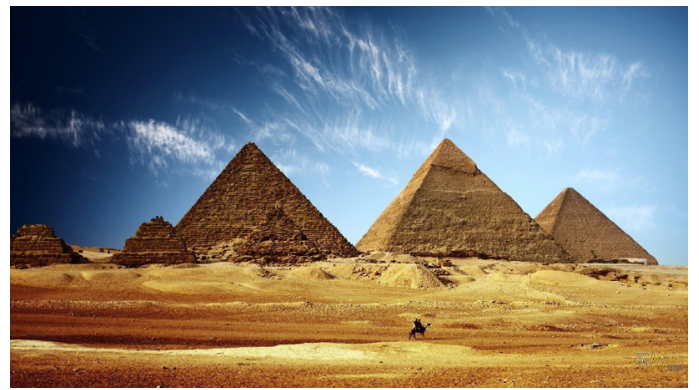

Fuente: <https://reydekish.com/2014/05/18/la-gran-piramide-de-giza/>. Acceso en: 12 abr. 2018.

Los criterios que rigen el conjunto funerario de las pirámides de Giza como representación del poder faraónico son compartidos por las estructuras piramidales de Sudamérica de las culturas mayas y aztecas, con Chichen Itza o las pirámides del conjunto de Tiahuanaco, en México. Monumentos funerarios, religiosos y de poder. Las culturas que los construyeron están reflejadas en estos monumentos, son pirámides que culminan su gran altura con el espacio del sacerdote que impone penas o castigos, un acceso formado por escaleras de gran pendiente que obliga al acusado ascender con la cabeza agachada sin vista hacia el futuro inmediato.
Figura 5 - Pirámide de KukulKan, Yucatán, México, siglo $\mathrm{V}-\mathrm{X}$

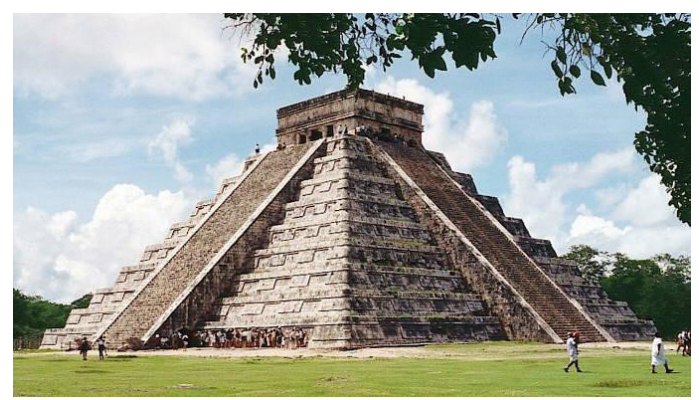

Fuente: <http://www.elmundo.es/cultura/2016/11/17/582d7e21 ca4741e3168b459f.html>. Acceso en: 21 jun. 2018.

Todos estos tesoros de la obra humana comienzan a conocerse y ha ser valorados a raíz del incremento del interés en las expediciones a lugares remotos, selvas o desiertos, que se genera durante el siglo XIX y los trabajos de recuperación física que se plantean en esos momentos con diferentes teorías. La tumba de Agamenón en Micenas, un imponente espacio de geometría cónica o el Mausoleo de Halicarnaso, son monumentos fúnebres que inmortalizan el poder de los reyes o su trascendencia. Una de las aportaciones más innovadoras del Mausoleo fue dotar de una nueva dimensión a la arquitectura y la escultura en un mismo espacio compartido, con un equilibrio que tendría numerosas réplicas posteriormente. La peculiar visión de la inmortalidad que transmite la tumba de Mausoleo inspiró numerosos monumentos griegos y romanos, que con el tiempo dio origen a la palabra "mausoleo", referido a cualquier monumento funerario de grandes dimensiones. 
Figura 6 - Tumba de Agamenón, Micenas

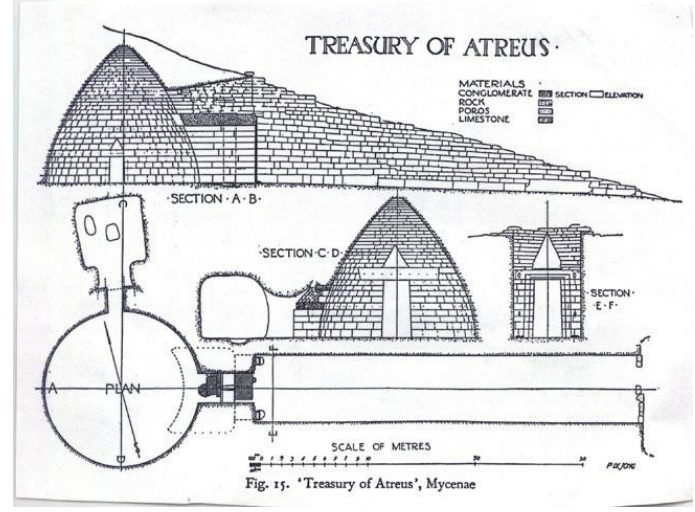

Fuente: <https://www.tes.com/lessons/tC_PaOoP1FaU6Q//-arte-micenea>. Acceso en: 10 mayo 2018.

El imperio romano se hace inmortal a través de grandes obras monumentales, 27 años a. C., Agripa construye en Roma, el Panteón en honor a los dioses y así mismo, como consta inscrito en su fachada. 130 años después el emperador Adriano, lo interviene y se convierte en uno de los monumentos más trascendentes de la humanidad, tanto por sus contenidos simbólicos y la belleza de sus proporciones espaciales como por el logro tecnológico que representa su cúpula con el óculo que la ilumina cenitalmente. Pruebas de una civilización de gran desarrollo en su cultura, en sus tecnologías constructivas y en sus tácticas militares. Perdido el poder de Roma, la humanidad entra en la convulsa época medieval entre las luchas de conquistas y defensas de territorios. Aparecen los eremitas, monjes que se instalaban en pequeñas cuevas escarbadas que dieron lugar a importantes monasterios.
Figura 7 - Mausoleo de Halicarnaso, Turquía, Siglo IV a. C.

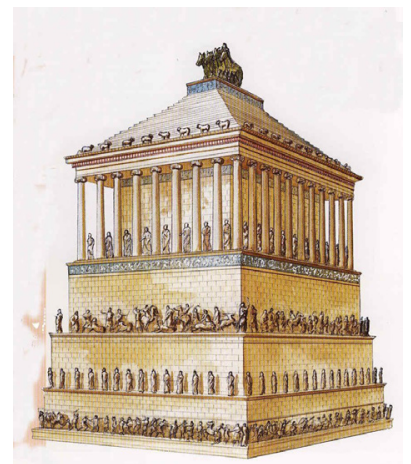

Fuente: <https://www.google.co.ve/search?biw=1>. Acceso en: 28 mar. 2018.

Figura 8 - Monasterio de Suso, San Millán de la Cogolla, La Rioja, España, Siglo IV-XI

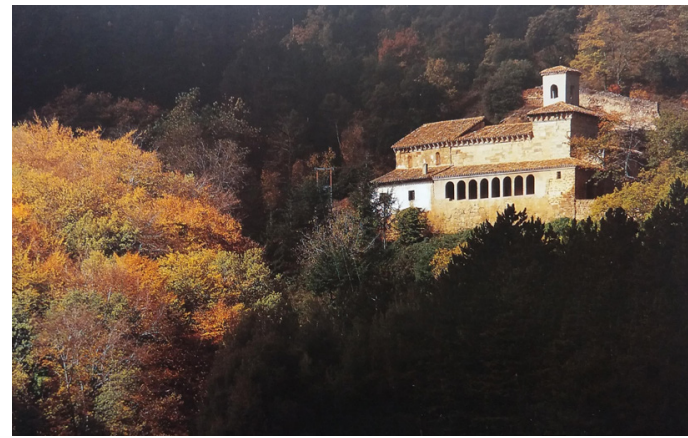

Fuente: Olarte (2005, p. 134).

San Millán de la Cogolla es un conjunto formado por dos monasterios, Suso y Yuso. Fue centro del poder político y cultural del medievo. El actual monasterio de Suso es el resultado de su permanente ampliación y reconstrucción entre los siglos VI al XI, contiene vestigios de los diversos momentos históricos en que se ha desarrollado, desde la primigenia cueva rupestre donde vivía el eremita fundador, el primitivo cenobio visigótico, la ampliación mozárabe y finalmente la románica. 
Cuatro civilizaciones diferentes dejan sus huellas en su arquitectura, muros y arcos visigodos, bóvedas de estilo califal y arcos de herradura, piedras esculpidas, pinturas, dibujos y textos sobre sus paredes. Este duro texto histórico se acompaña de una fundamental colección de manuscritos y códices, como el Códice Emilianiense fechado

Figura 9 - Planta del monasterio, cueva del ermita y las ampliaciones posteriores

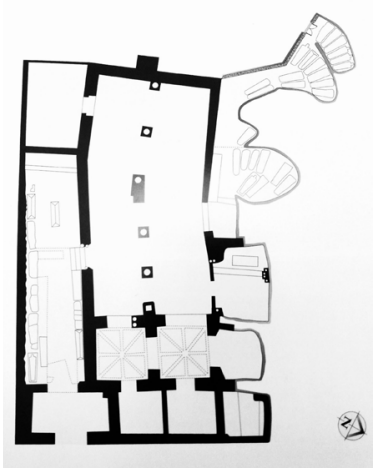

Fuente: Olarte (2005, p. 142).

Figura 11 - Nave central del santuario, arcos romanos y mozárabes, La cuna del castellano

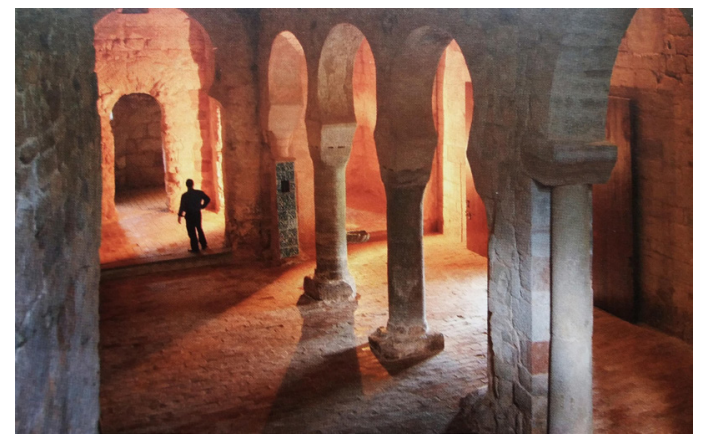

Fuente: Gobierno de La Rioja. en el año 992, y el Códice 46 escrito en latín, en una de sus esquinas presenta un pequeño texto con las primeras palabras en castellano, primer vestigio de la lengua compartida por 400 millones de personas en el mundo. A través de las restauraciones y ampliaciones sucesivas, es a la vez tumba, templo y centro de poder de la cultura.

Figura 10 - Cueva sepulcral

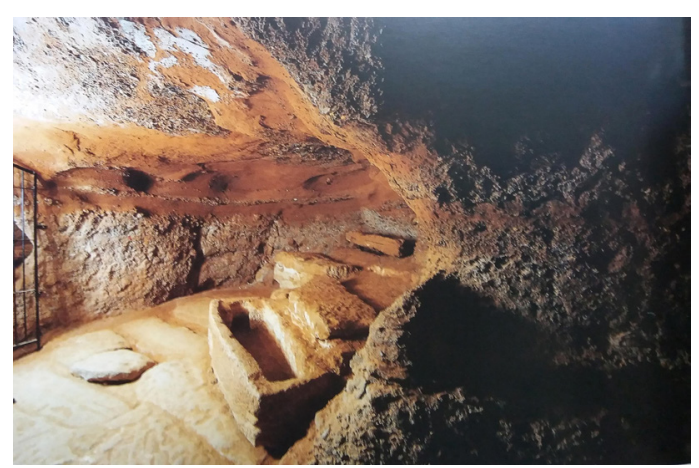

Fuente: Olarte (2005, p. 143).

En China durante el siglo III a. C. se crea la necrópolis del emperador Qin que construye una ciudad subterránea y reproduce a escala el palacio del emperador, el imperio y la tierra incluyendo su ejército, "los guerreros de terracota" que representan un hito en la escultura china. ¿Qué mejor síntesis entre la muerte, el culto y el poder guardados para la eternidad?

Los conjuntos de tumbas imperiales de la dinastía Ming, ya para el siglo XV, siguen los mismos preceptos, con las cambios producidos por las evoluciones religiosas y los criterios de geomancia, pero mantienen 14 tumbas, dos templos budistas y el palacio de la familia imperial. 
Figura 12 - Los guerreros de terracota, Xian, China, siglo III a. C.

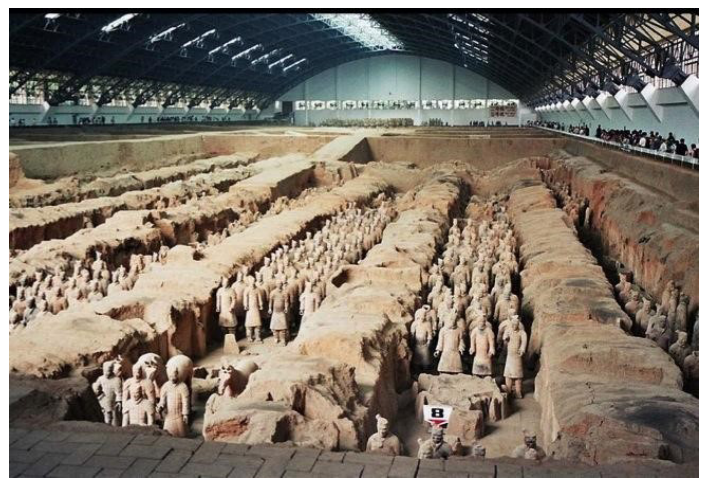

Fuente: <http://www.viajerototal.com/2015/11/guerreros-de-terracota-de-xian-mausoleo.html . Acceso en: 27 mayo 2018.

El mausoleo Taj Mahal, es una joya de la arquitectura multicultural del siglo XVII, monumento a la esposa del emperador musulmán Shah Jahan, cuyo sepulcro esta ubicado bajo la gran cúpula de la sala octogonal. En 1830 se intentó desmontarlo y vender sus partes en Inglaterra y a comienzos del siglo XX otro inglés se dedicó a conservarlo para la posteridad.

Figura 13 - Tah Majal, Agra, India, siglo XVII

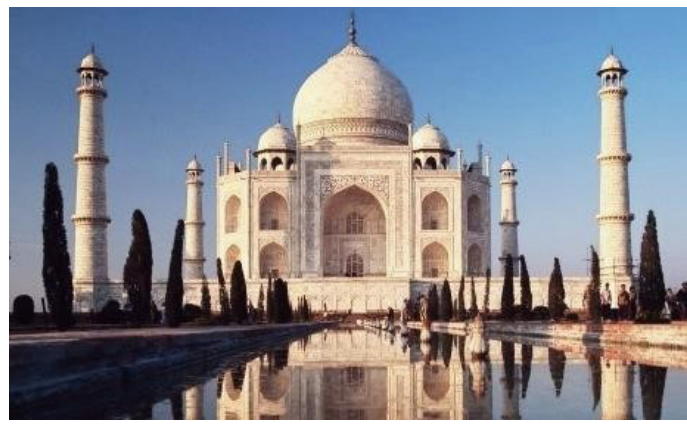

Fuente: <http://servicioseducativos.over-blog.org/article-el-taj-mahal-una-de-las-7-maravillas-del-mundo-79540151. html>. Acceso en: 13 jun. 2018.

Si el Tah Majal, es un poderoso mausoleo real que podríamos considerar como un monumento a la tristeza de la pérdida del amor humano, la Alhambra de Granada, es un canto a la vida.
Figura 14 - Patio de los Leone, Alhambra de Granada, siglo XII-XIV

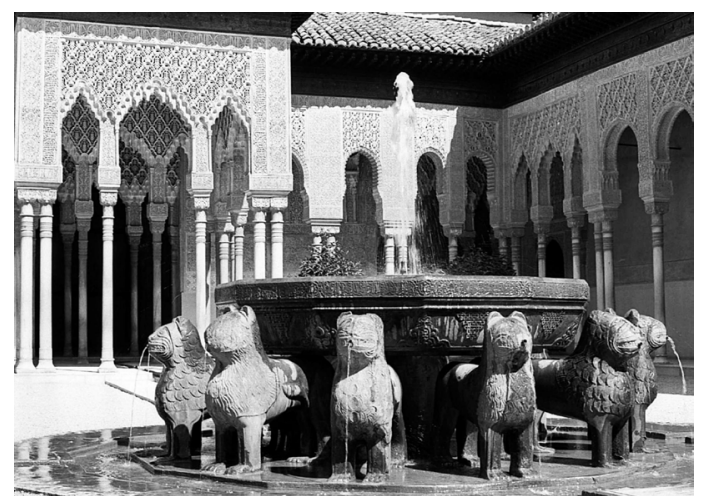

Fuente: <https://www.google.com/search?q=patio+de+los+le ones+alhambra\&client=firefox->. Acceso en: $30 \mathrm{abr}$. 2018.

El conjunto monumental de la Ciudad y Palacios Nazaríes de la Alhambra de Granada define el horizonte del paisaje urbano de la ciudad por la silueta de la antigua ciudad palatina nazarí, de los siglos XIII-XV. El conjunto forma un inmenso paisaje cultural vivo y cambiante forjado a través de 7 siglos y distintas culturas desde la musulmana que la crea, la renacentista que la adopta e interviene, los periodos de abandono y saqueo y la recuperación desde diversos puntos de vista, que hasta el presente mantiene su cuido físico, el estudio continuo y la interpretación de sus significados. Muestra clara de las diferentes culturas que la definieron, en continuo cambio y ampliación según las condiciones sociales de cada etapa de su recorrido temporal. Un texto de piedra legible e interpretable, arquitectura que da pie a la música, la literatura y definitivamente a la poesía. 
Figura 15 - Alhambra de Granada: con el fondo de la sierra Nevada, se recorta su perfil que define la ciudad.

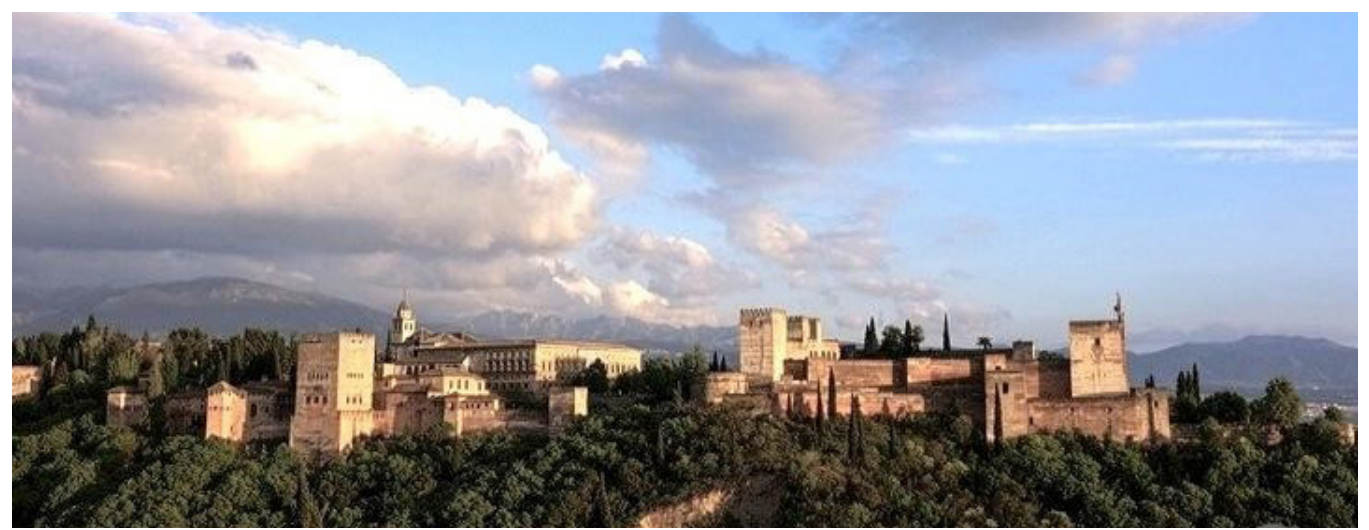

Fuente: Guia oficial [2000].

Figura 16 - En el monte Sabika a 100 m sobre el suelo de Granada, la Alhambra la contempla.

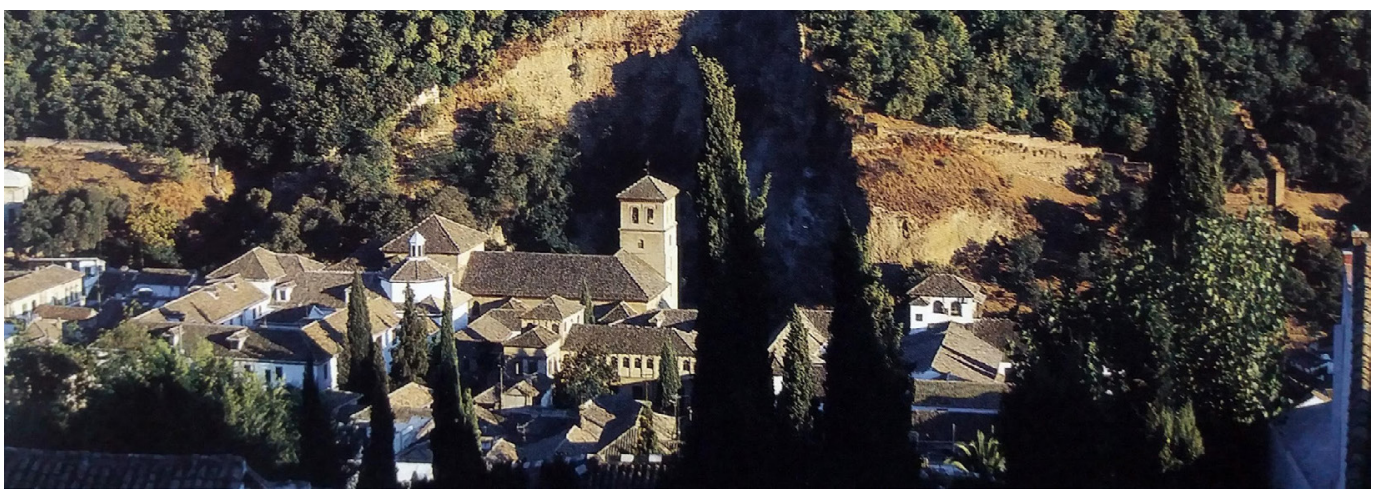

Fuente: Guia oficial [2000].

Mezquita, muralla defensiva, sede del poder y residencia real de las numerosas dinastías del emirato de Granada, todo ello trabajado con las mejores respuestas al medio, incluyendo en su interior la frescura de los jardines y el sonido del agua. Genera patios como espacios físicos que se superan así mismos y se convierten en un concepto arquitectónico que reúne el aire, el sol y el agua, que no solo cumplen su propósito climático, sino que a través de la idea de Arquitectura se transforman en poesía construida, completándose así su destino final que es la belleza. 
Figura 17 - Plano de planta. Grabado XXXI. Litografías ejecutadas según sus cuadros, planos y dibujos hechos sobre el terreno en 1938.

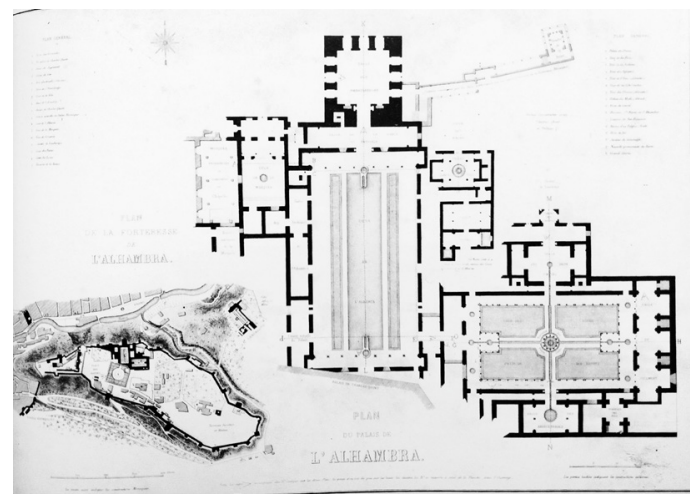

Fuente: Prangey (1985, p. 293).

En 1859 se iniciaron trabajos de restauración en la Alhambra destinados a reparar deterioros y a su conservación física, según las líneas generales de las teoría establecida por Viollet le Duc, de Restauración Estilística, en la cual se planteaba que "restaurar un edificio no es solo repararlo o conservarlo", es restituirlo a un estilo de plenitud "que puede no haber existido" con estos parámetros se restauró, reformando numerosos elementos según el patrón que se mantenía de un idealizado estilo "árabe". Entre los años 20 y 30 se intervino nuevamente con los principios que imponía la Carta de Restauración de Atenas de 1931, donde se plantea entre otras cosas, el respeto absoluto de la obra histórica y artística del pasado y el empleo de técnicas modernas y materiales nuevos siempre que sean reconocibles.
Figura 18 - Corte por el patio de los Leones. Grabado XXIV. Litografías ejecutadas según sus cuadros, planos y dibujos hechos sobre el terreno en 1938.

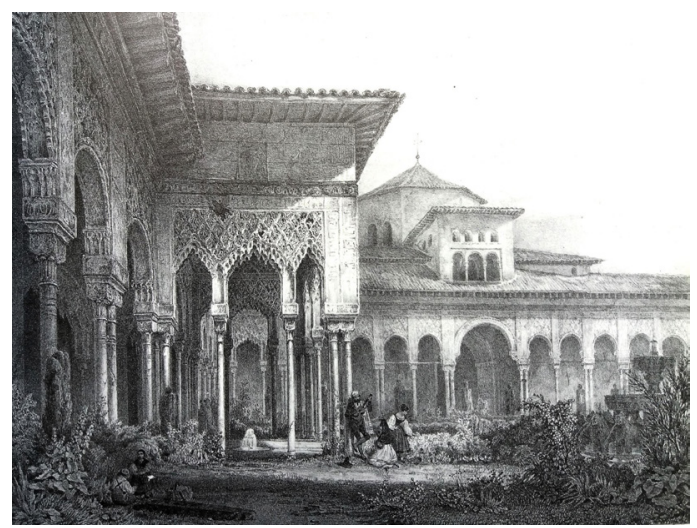

Fuente: Prangey (1985, p. 294).

Figura 19 - Detalles. Grabado V. Litografías ejecutadas según sus cuadros, planos y dibujos hechos sobre el terreno en 1938.
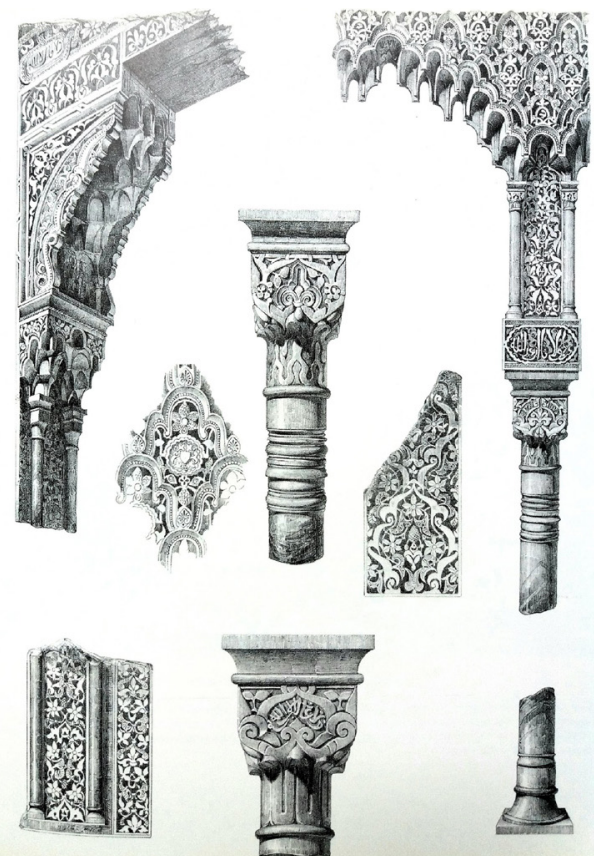

Fuente: Prangey (1985, p. 300) 
La Alhambra de Granada en el siglo XXI sigue dando luz, sombra y color al espacio de la libertad creadora, ofreciendo la experiencia del arte, aquella que hace propia del ser humano la comprensión de sus valores universales.

Figura 20 - Patio de Los Arrayanes (la alberca en el eje central y al fondo la torre de Comares)

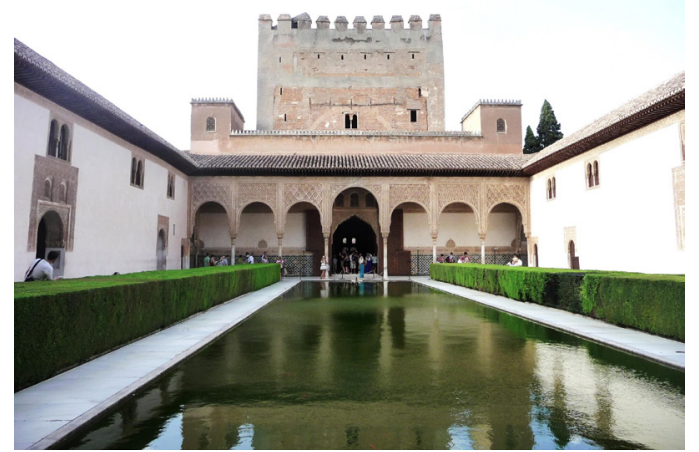

Fuente: <https://granadapickups.blogspot.com/2018/05/alhambra-patio-de-los-arrayanes.html>. Acceso en: 13 mayo 2018.

Figura 21 - Patio de los Leones (patio rectangular con fuente central y galería porticada en sus cuatro lados)

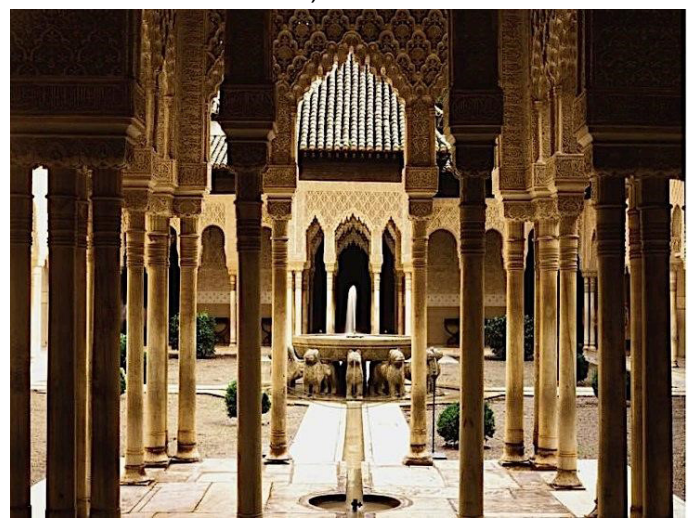

Fuente: <https://twitter.com/lobolibreg>. Acceso en: 31 mayo 2018.

\section{Arquitectura domestica... da}

La ciudad es el escenario de la vida colectiva y su materialidad propone referencias concretas que apelan a la memoria, también las pautas de comportamiento, ritos, costumbres, etc. que operan en la representación cotidiana, se complementan para constituirse en condiciones esenciales para el mejoramiento de la calidad de vida del cuerpo social. Las ciudades son organismos de desarrollo lento que evolucionan a través del tiempo, conformadas por espacios definidos por las masas edificadas y los vacíos que generan el espacio público. La mayor parte de la obra construida esta dedicada a la vivienda. Esta arquitectura doméstica sin reconocimiento por largo tiempo, es el lugar donde se desarrolla la vida cotidiana y el cobijo diario de los protagonistas anónimos que pueblan las ciudades. Nace la casa colonial americana transportada en frágiles navíos a través del espacio y el tiempo, como una tradición constructiva comprobada por diferentes culturas, que se establece en toda América. Caracas para el momento, es una modesta ciudad con la condición de Capitanía General a diferencia de Lima o Cartagena de Indias.

Su centro fundacional contiene las edificaciones importantes para su definición espacial, en su expansión se desarrollan áreas periféricas dedicadas al cultivo y cría de ganado como actividad rural que se ejerce en las casas de hacienda. Muchas de estas edificaciones del siglo XVII se perdieron, por abandono, desgaste de su materia o descuido del legado que recuerda a los ciudadanos quienes son. Los grandes territorios 
ocupados por estas haciendas han quedado en su mayoría, rodeados por el desarrollo de la ciudad, autopistas, avenidas y grandes fachadas urbanas son sus linderos que los convierte en grandes parques urbanos donde se desarrolla la cultura.

La Hacienda La Floresta se funda en 1783 en los antiguos terrenos de la Hacienda Santa Ana, ubicada entre el Camino Real de Petare en el norte y el rio Guaire en el sur. En sus extensos terrenos dedicados al cultivo de café se mantiene la producción agrícola durante los siglos XVIII y XIX. Su antigua casona de finales del siglo XVIII, se recupera de los daños ocasionados por el terremoto de Caracas de 1812. Después de varios cambios de propietario, en 1988 comienzan los trabajos de restauración bajo la dirección del arquitecto R. Paolini, posteriormente es adquirida por Petróleos de Venezuela y se establece como Centro de Arte La Estancia, abierta al público en 1995 y destinada a la difusión cultural.

Los criterios de conservación aplicados valoran su arquitectura con una aproximación contemporánea en la que se combinan las piezas originales restauradas con los nuevos elementos, en un dialogo de respeto que permite recuperar la memoria de un pasado que se hace presente. Sus espacios domésticos, corredores, patios interiores, habitaciones, el patio de caballerizas, la cocina, se trasforman en nuevos usos sin perder su presencia. Esta casona está ubicada en tres hectáreas de territorio con un paisajismo de grandes árboles centenarios, a través de los cuales se vislumbra el futuro que está presente en la fachada contemporánea de la ciudad.
Figura 22 - Centro de Arte La Estancia, Casona de la Hacienda La Floresta, 1783-1995

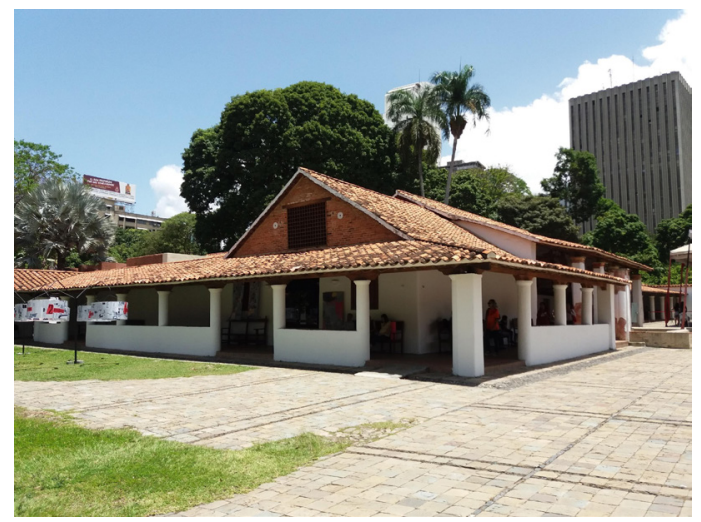

Fuente: acervo de la autora.

Figura 23 - Centro de Arte La Estancia, jardines de acceso principal

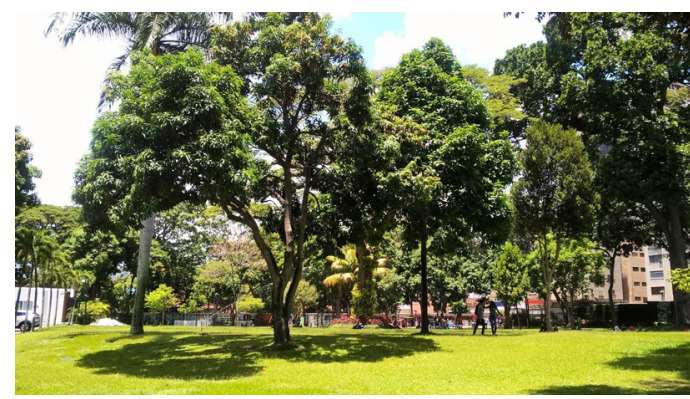

Fuente: acervo de la autora.

Figura 24 - Centro de Arte La Estancia, galerías cubiertas

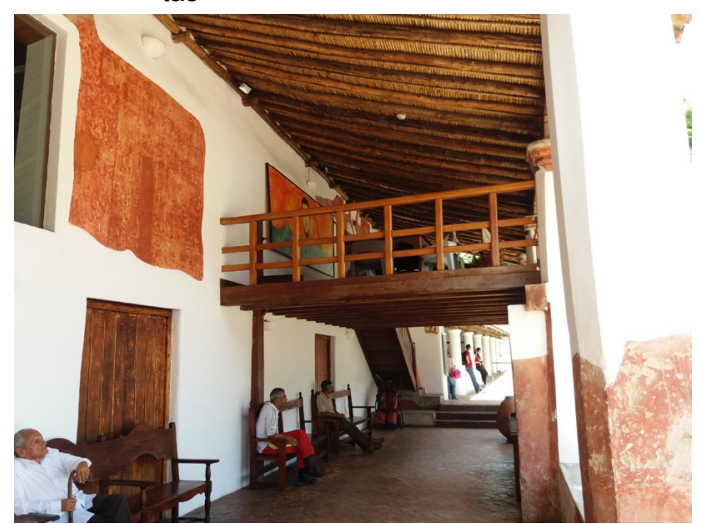

Fuente: acervo de la autora. 
Figura 25 - Centro de Arte La Estancia, Caballerizas, espacios intervenidos con usos sociales

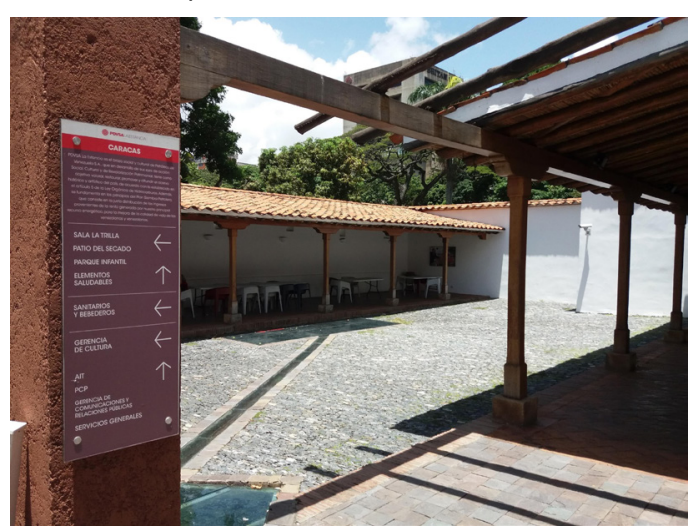

Fuente: acervo de la autora.

Anauco Arriba es la casa de hacienda más antigua conservada en su ubicación original. Construida en 1632 en los terrenos altos, camino del cerro Ávila, hace posible que su lejanía de los territorios de violento crecimiento urbano haya podido superar la ola demoledora que acabó con muchas edificaciones coloniales.

Esta pequeña hacienda dedicada al cultivo y la cría de ganado, a través de sus vivencias, narra la historia de la economía rural del siglo XVII. Casa de tapias con cubierta de tejas, núcleo inicial de esta vivienda colonial. Crece integrándose con otras fincas de cultivo y perteneciendo a diferentes propietarios por trescientos años. Durante este proceso se llevan a cabo numerosas intervenciones descontroladas, que destruyen elementos básicos de su estructura original, sin embargo una buena parte de ella ha podido preservar sus condiciones originales, con lo cual todo el inmueble re- cobra un importante valor para la memoria histórica y arquitectónica. En la actualidad trasciende su concepción originaria de vivienda privada y se convierte en un Centro de participación popular, con actividades culturales y recreativas al servicio de la ciudad.

Figura 26 - Anauco Arriba, portón de entrada (16321995)

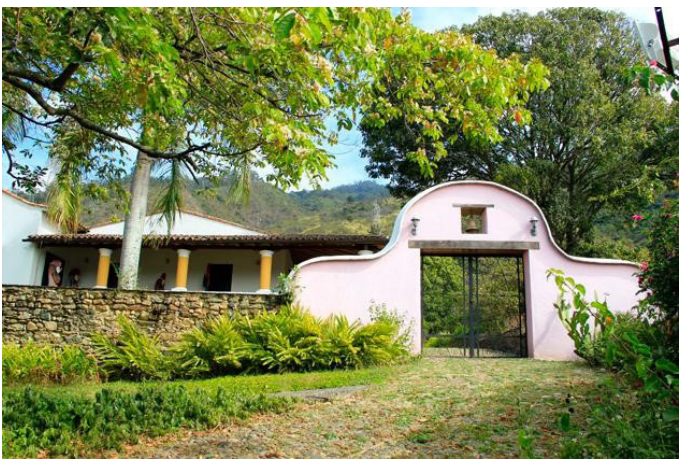

Fuente: acervo de la autora.

Figura 27 - Anauco Arriba vista de la galería

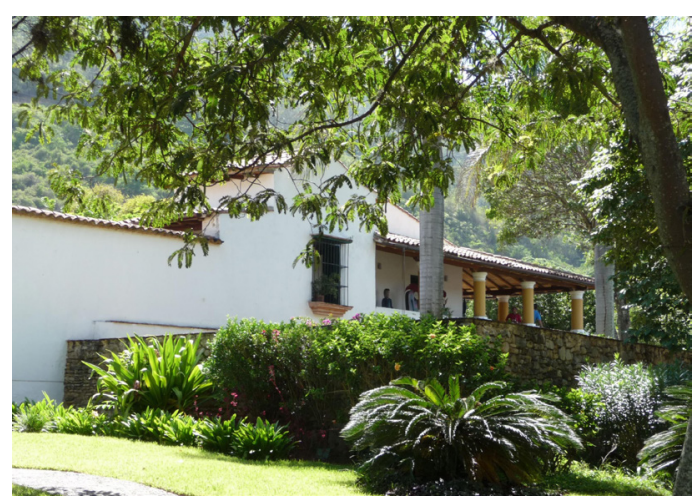

Fuente: acervo de la autora. 
Figura 28 - Vista del Ávila, 1940 (Oleo: Manuel Cabré, el pintor de El Ávila)

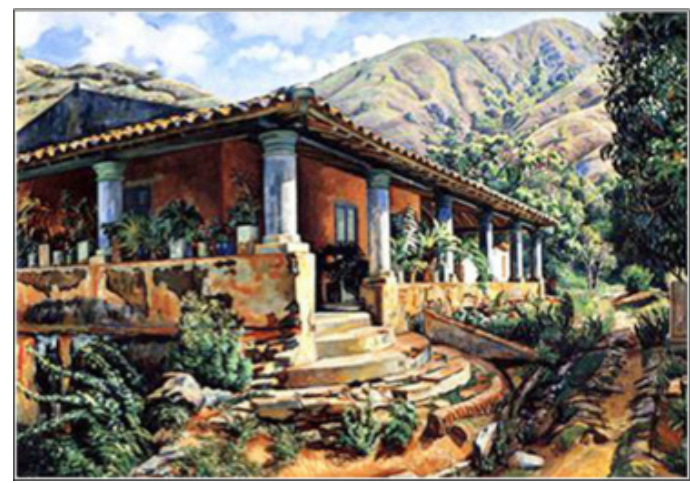

Fuente: <http://alileninaguileramarciales.co>. Acceso en: 30 mayo 2018

La Hacienda La Trinidad ubicada en el sureste de la ciudad es una de las más recientes recuperaciones de estas construcciones periféricas dedicadas a la producción agrícola. El crecimiento de las urbanizaciones donde esta se ubica, la situó en nivel de riesgo con sus avances, los que fueron controlados en 1970 cuando se preservaron los terrenos ocupados por sus principales construcciones y su marco natural, como refugio de la memoria histórica. El conjunto esta formado por la Casa Vieja de la Hacienda del siglo XVIII, que responde a las pautas establecidas para estas viviendas aisladas de las zonas urbanas, con su arquitectura doméstica de patios y corredores techados, y la Casa del Trapiche de la misma fecha, donde se procesa la caña de azúcar, los Secaderos de tabaco se construyen a mediados del siglo XX. Estas instalaciones se corresponden con los diferentes cultivos de sus terrenos, caña de azúcar, café y tabaco a lo largo de dos siglos.
Figura 29 - Hacienda La Trinidad, parque cultural, Casona de Hacienda, siglo XVIII

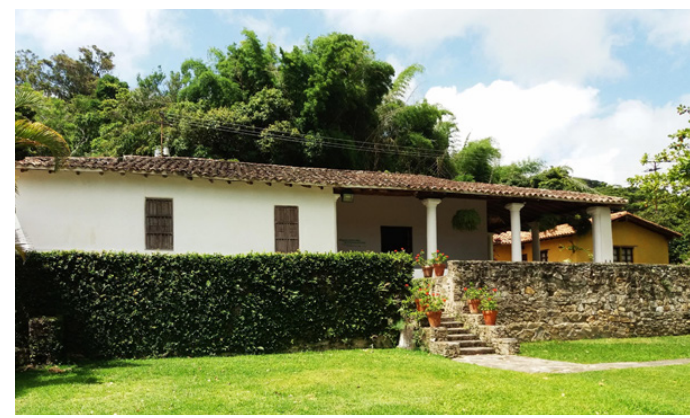

Fuente: acervo de la autora.

Con su última renovación en el 2012, constituye un caso único de preservación, que ha logrado hacer de este espacio un centro cultural autosustentable con galerías de arte, artesanía tradicional, diseño contemporáneo, y un laboratorio dedicado a la investigación sobre el cacao. Un espacio compartido en el que la naturaleza, la historia y la cultura se conjugan.

Figura 30 - Hacienda La Trinidad, parque cultural, Los Secaderos

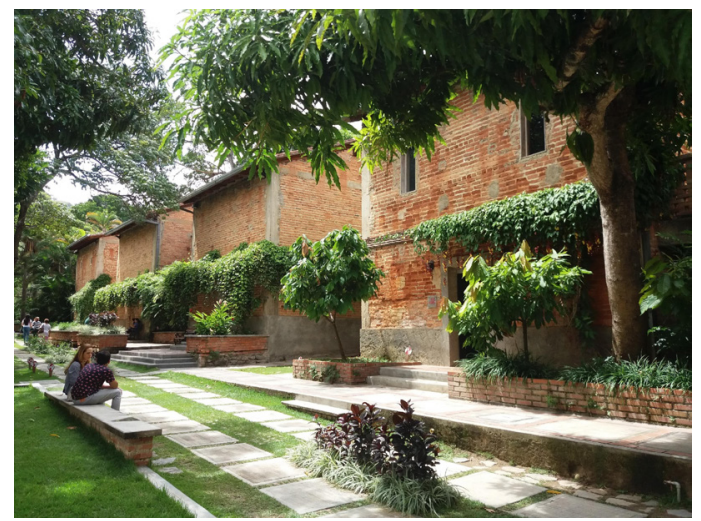

Fuente: acervo de la autora. 
Figura 31 - Hacienda La Trinidad, parque de acceso, Los Secaderos como fondo

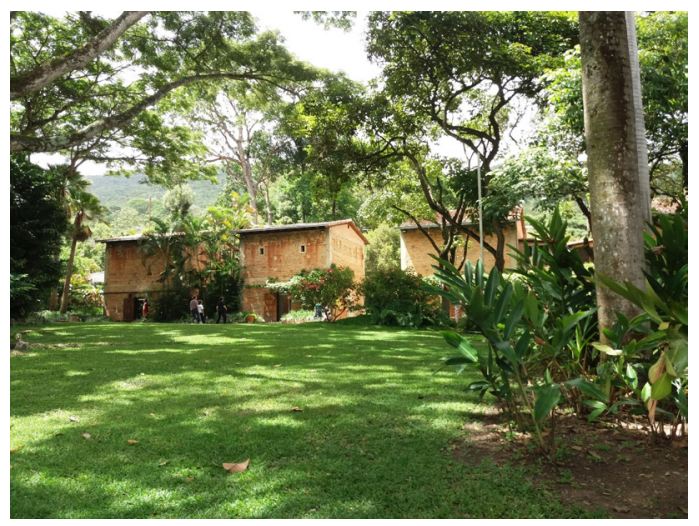

Fuente: acervo de la autora.

\section{Fin de viaje}

El viaje de retorno a nuestros conocimientos no siempre cumple los anhelos ansiados por el recuerdo. Ítaca ha cambiado a través del tiempo y de los eventos enfrentados, pero no es solo ella, el viajero que partió a su vez es otro. El recorrido le ha enriquecido y no importa cuándo o a dónde se llega, el camino le ha hecho crecer. Todas las arquitecturas que se han revisado, son parte del camino a recorrer, su permanencia física o histórica por medio de imágenes, permite entender el pasado desde el presente como futuro. Este recorrido a través de las piezas seleccionadas desde el poder, el culto o la muerte, así como también y por contraste, de esas arquitecturas íntimas donde se desarrolla la vida cotidiana, generan en el lector diferentes recuerdos o vivencias. Cada una produce una opinión, una creencia o una visión, que da lugar a diferentes historias... tantas como lectores, íntimas o colectivas.
La suma de una nueva capa en la historia viva y cambiante de las ciudades deja la huella de su momento, esta será leída como otra página del libro creado y reescrito por las múltiples manos de los habitantes que cotidianamente leen sus páginas y con su memoria son los forjadores de las ciudades. Este recorrido revela a cada uno un camino distinto, una interpretación diferente, una odisea única y propia...

Conserva en tu alma la idea de Ítaca, llegar allí es tu destino...

Ítaca te ha concedido ya un hermoso viaje, sin ella jamás abrías partido... (KAVAFIS, 1999, p. 31).

\section{Abstract}

The saga of man is a journey without return, from its nomadic condition to urban settlements, gives rise to differentiated values that define the different cultures that are expressed physically, through the architectures that define spaces and cities. The reading of human history as accumulated memories, has multiple possibilities to be reviewed in books or stories, in physical or virtual images that give the reader the opportunity to reconstruct their own history, personal or collective, through different interpretative readings. These constructed realities are subject to constant evolution through time and the vicissitudes that have taken place. Only its care and maintenance guarantee its continuity through the preservation of memory and memories in its fight against oblivion.

Keywords: Architecture. Image. Memory. 


\section{Resumo}

A saga do homem é uma jornada sem retorno, da sua condição nômade aos assentamentos urbanos, dá origem a valores diferenciados que definem as diferentes culturas que se expressam fisicamente, por meio das arquiteturas que definem os espaços e as cidades. A leitura da história humana como memórias acumuladas tem múltiplas possibilidades de ser revista em livros ou histórias, em imagens físicas ou virtuais, que dão ao leitor a oportunidade de reconstruir sua própria história, pessoal ou coletiva, por diferentes leituras interpretativas. Essas realidades construídas estão sujeitas à constante evolução através do tempo e das vicissitudes que ocorreram. Somente seu cuidado e sua manutenção garantem sua continuidade por meio da preservação da memória e de memórias em sua luta contra o esquecimento.

Palavras-chave: Arquitetura. Imagem. Memória.

\section{Notas}

Constantino Kavafis (1836-1933) es poeta egipcio-griego. Su poema Ítaca se publica en 1911.

2 Ludwig Mies van der Rohe (1886-1969) dirigió la escuela Bauhaus entre 1930 y 1933. Junto con sus contemporáneos Walter Gropius, Le Corbusier y Frank Lloyd Wright, son considerados los mayores arquitectos del siglo XX.

\section{Referencias}

BARTHES Roland. La cámara lúcida. Notas sobre la fotografía. Barcelona: Paidos, 1990.

GUIA OFICIAL. La Alhambra y el Generalife. Consejería de Cultura. Junta de Andalucía, España: TF Editores, [2000].

KAVAFIS, Constantino. Antología Poética. Ítaca. Madrid: Alianza Editorial, 1999. Disponible en: <http://www.pixelteca.com/rapsodas/ kavafis/itaca.html>. Acceso en: 30 ago. 2018.

LIZARAZO, Diego. Iconos, figuraciones, sueños: la hermenéutica de las imágenes. Diseño y comunicación. México: Siglo XXI, 2004.

MUNTAÑOLA, Josep. Arquitectura, proyecto y memoria - UPCommons. 2002. Disponible en: <https://upcommons.upc.edu/bitstream/handle/2099/12021/DPA\%2018_6\%20 MUNTA\%20OLA.pdf?sequence=1>. Acceso en: 29 ago. 2018.

OLARTE, Juan. San Millán de la Cogolla, Suso y Yuso. León: Edilesa, 2005.

ORWELL, George. 1984. 1949. Disponible en: $<$ www.lecturalia.com/autor/238/george-orwell>. Acceso en: 30 ago. 2018.

PEREZ ORAMAS, Luis. Arquitecturas. Mirar Furtivo. Consejo Nacional de la Cultura CONAC. Caracas: Armitano, 1997.

PRANGEY, Girault de. Litografías Paris, 1837. Recuerdos de Granada y de la Alhambra. Barcelona: Escudo de Oro, 1985.

RICOEUR, Paul. Arquitectura y narratividad. In: MUNTAÑOLA, Josep. Arquitectura y Hermenéutica. Barcelona: Ediciones IPC, 2002. p. 9-29. Disponible en: <http:// socfront.flacso. edu.mx/?page_id=606>. Acceso en: 30 ago. 2018.

VILCHES, Lorenzo. La lectura de la imagen: prensa, cine, televisión. España: Paidos, 1984. 